\title{
Inheritance of resistance to (NGR1) pathogen isolates of Pyricularia grisea in GULU-E finger millet last resistant variety of Uganda
}

\author{
J.C. Aru', N. Wanyera' ${ }^{1}$ and P. Okori ${ }^{2}$ \\ ${ }^{1}$ National Semi Arid Resources Research Institute, Serere, P. O. Soroti, Uganda \\ ${ }^{2}$ International Crops Research Institute for the Semi-Arid Tropics, P. O. Box 1096, Lilongwe, Malawi
}

Author for correspondence: arucharles40@yahoo.com

\begin{abstract}
Finger millet is basis for food security which directly supports the livelihoods of rural majority living in marginal areas in East Africa. Gene action and heritability of blast resistance in GULUE finger millet was determined from crosses between GULU-E as female parent mated to four susceptible genotypes, using the North Carolina 1 crossing design, to determine nature of resistance. Inoculation of finger millet with a fungus, Pyricularia grisea, which causes blast, was done using one potentially most virulent local pathogen isolate (NGR1) identified from Ngora district, in Odwarat parish, which is one of the pathogen hotspots of eastern Uganda . It was identified following isolate screening trial for virulence in Makerere University, during $2012 \mathrm{~b}$. $F_{1}, F_{2}$ and backcrosses were evaluated under controlled conditions. Disease reaction indicated that resistance was partially dominant and additive, based on mid parent values from crosses. Segregating ratios and Chi-square tests of $F_{2}$ populations fitted 13R:3S genetic model, indicating presence of duplicate dominant epistasis at a probability level of 0.05 . Broad-sense heritability estimated by the variance components method was high $(\mathbf{8 8 . 8 \%})$ on entry mean basis. Selection for resistant progeny derived from crosses between GULU-E and DR21 finger millet would be most effective in early generations, followed by modified backcrossing at $F_{3}$ to the adapted recurrent resistant parent, leading to diversification of a population and derivation of materials for selection for disease resistance. From the study it is possible to accumulate genes for race specific resistance in host cultivars that might reduce development of disease epidemics in some areas. The genetic control of components of resistance and mechanisms of resistance in the host which affect the rate of development of disease epidemic, need to be determined, since they are important variables for durable resistance.
\end{abstract}

Key words: Broad sense heritability, durable resistance, modified backcrossing, virulence 


\section{Introduction}

Finger millet is basis for food security which directly supports the livelihoods of rural majority living in marginal areas of Uganda. These consist of traditional and new cultivars grown by farmers; however, new high yielding cultivars have been characterised by lack of durability of resistance to blast disease caused by fungus, pyricularia grisea, one of the key biotic constraint to finger millet production in East Africa. Lack of sustainability of resistance is caused by break-down of a single gene, which confers resistance (Takan et al., 2011). The frequency of break-down of varieties is predicted to increase following the recent variability in weather and this will affect livelihoods of people who depend on finger millet .The breakdown can occur immediately after release or sometimes even before breeding lines reach on- farm. Durability of resistance is a vital component of food security, therefore it is imperative to breed for varieties that are stable.

There are efforts in Malawi and Uganda to breed for durable resistance to pathogen populations in our environment, using locally adaptable varieties. The major components of this control strategy are identification of local genetic sources of resistance and deployment of resistance genes. GULU$\mathrm{E}$ is local variety released in 1960's and grown in north eastern agro-ecology of Uganda and has maintained it's disease resistance reaction through test seasons and locations. It is used as blast resistant check in many pathological studies in testing for virulence and race identification (Adipala and Wandera, 2001). Therefore, for the purpose of initiating breeding for durable resistance, GULU-E has a potential for providing the necessary genetic variability for selection. However, there is limited information on the nature of genetic inheritance of genes controlling blast resistance in this local variety. This information is important in developing a breeding plan for efficient transfer of resistance into breeding lines, thus leading to development of durable finger millet varieties for release (Getachew Gashaw et al., 2013). Therefore, the purpose of this study was to determine gene action in GULU-E as a basis of a breeding strategy for incorporating blast resistance on to elite breeder's lines.

\section{Materials and methods}

\section{Experimental design}

Gene action and heritability of blast resistance in Gulu-E was determined from crosses between GULU-E as female parent, mated to four susceptible genotypes (Table 1), using North Carolina 1 crossing design producing halfsib progenies that were selfed to $F_{2}$. Inoculation was done using one potentially most virulent local pathogen isolate (NGR1) identified from Ngora district, one of the pathogen hotspots of eastern agroecology and major finger millet growing area (Adipala.E and Wandera. 2001 and Takan et al., 2004). It was identified following isolate screening trial for virulence in Makerere University during 2012b (Aru et al., 2014). The $\mathrm{F}_{1}, \mathrm{~F}_{2}$, parents and some successful backcrosses making all together 16 entries, were evaluated under controlled conditions high humidity at $96 \%$ and temperature of $22^{\circ \mathrm{cc}}$ necessary for infection. The trial was laid in randomised complete block design (RCBD), replicated five times. Data were taken on five plants per pot. Means subjected to analysis of variance, regression analysis, Chis-square test of 
goodness of fit and component of generation means.

\section{Inoculation and disease assessment}

Inoculum preparation was according to nature protocols for preparation of longterm stocks of virulent magnaporthe grisea (David, 2008). Inoculation was done at 55 days after planting (DAP), corresponding with field resistance, when race-specific genetic factors are more strongly expressed compared seedling stage. At maturity stages (from flower initiation to physiological maturity), proper identification of traits with good adaptations which constitute components of yield in finger millet is possible such as number of fingers, length of fingers and size of seed. In breeding for durable resistance, it is important to accumulate genes for race specific resistance, resulting in decrease of fitness or aggressiveness of the pathogen, which reduces development of disease epidemics (Mukankusi et al., 1999). Data were taken on area of the leaf covered by lesions (Takan et al., 2002) and on number of days from inoculation to infection of flag leaf (appearance of monogenic chlorotic lesions). These variables indicate the rate of pathogen growth in the plant. The difference between inoculation and infection reflects the differences in the growth rate of the pathogen in the host and is component of partial resistance (Adipala and Wandera, 2001).

\section{Statistical analysis}

Inheritance of blast resistance was computed using regressions analysis, Chissquare test of goodness of fit and estimation of components of generation means based on theoretical expectations ( Singh and Chaudhary, 2007) 


\section{Results}

\section{Variability for flag leaf infection}

There was significant variance between genotypes $(\mathrm{P}<0.001, \mathrm{CV}=25.6 \%)$. The interval from inoculation to infection of the flag leaf provided means of differentiating genotypes (Table 2).

Heritability of blast resistance and type of gene action

Results from mid-parent regression on $\mathrm{F}_{2}$ progenies was significant, with moderate coefficient of regression $(b=0.28)$, which is narrow sense heritability (Table 3). Genotypes; IE2790, $\mathrm{F}_{2}$ GULU-E X KATFM1, BCF ${ }_{1}$ DR21 X GULU-E and
KATFM1 had the lowest number of days to infection of the flag below the grand mean of 21 days for the population. Meanwhile $\mathrm{F}_{2}$ GULU-E X KABALE, $\mathrm{F}_{1}$ GULU-E X DR21 had an average of 31 days from inoculation before infection of the flag leaf (Table 4). Analysis of change of mid parent from $\mathrm{F}_{1}$ showed presence of heterosis on either direction for days to infection of flag leaf (Table $5)$.

\section{Nature of genetic resistance}

Analysis of genes leading to these expression based on segregation ratios of resistant to susceptible genotypes (R: S) and testing their frequencies, we found that

Table 2. Analysis of variance for genetic differences among $F_{1} S, F_{2} S$, backcrosses and parents of crosses between GULU-E to susceptible finger millet genotypes based on period from inoculation with Pyricularia grisea to infection of the flag leaf

\begin{tabular}{lrrrll}
\hline Source of variation & DF & \multicolumn{1}{c}{ SS } & MS & VR & Fpr \\
\hline Rep & 4 & 250.45 & 62.61 & 2.03 & \\
Genotype & 15 & 2990.6 & 199.37 & $6.48^{* * *}$ & $<0.001$ \\
Residual & 60 & 1847.15 & 39.79 & & \\
Total & 70 & 5088.2 & & & \\
\hline
\end{tabular}

L.S.D $(5 \%)=7.01$, C.V $=25.6 \%$, S.E $=5.54, * * * *$ significant $=\mathrm{P}<0.001$

Table 3. Regression of mid-parent values on $F 2$ progenies for infection of the flag leaf by chlorotic lesions for estimating narrow -sense heritability the degree to which the genes for flag leaf resistance to are passed to offspring

\begin{tabular}{lcrcc}
\hline Source of variation & DF & SS & MS & F \\
\hline Regression & 1 & 2.93 & 2.93 & $58.6^{* *}$ \\
About regr(error) & 2 & 0.1 & 0.05 & \\
Total & 3 & 3.03 & & \\
\hline
\end{tabular}

C.V $\%=8.1, \mathrm{R}^{2}=0.72, \mathrm{~b}=0.28=\mathrm{h}^{2} \mathrm{n}, \mathrm{R}^{2}=$ Coefficient of determination $=1$-error MS/total MS is fraction of variation accounted for, $\mathrm{b}=$ regression coefficient $, \mathrm{Ho}=\mathrm{b}=0, * *$ Significance of the regression $(\mathrm{P}<0.01)$ 
Table 4. Days after inoculation with Pyricularia grisea to infection of flag leaf from $\mathrm{F}_{1} \mathrm{~S}, \mathrm{~F}_{2} \mathrm{~S}$, backcrosses \& parents crossed to GULU-E the resistant host in Makerere University Kabanyolo

\begin{tabular}{ll}
\hline Genotype (Crosses) & Mean \\
\hline BC1F 1 DR21 X GULU-E & 18.4 \\
BC1F_GULU-EXDR21 & 25.4 \\
F $_{2}$ IE2790X GULU-E & 11.2 \\
F $_{1}$ GUL-EXIE2790 & 21.6 \\
F $_{1}$ GULU-EX KABALE & 31.8 \\
F $_{1}$ GUL-EXDR21 & 31.0 \\
F $_{1}$ GULU-EXIE2790 & 21.2 \\
F $_{1}$ GULU-E X KAFM1 & 22.8 \\
F $_{2}$ GULU-EXIE2790 & 20.0 \\
F $_{2}$ GULU-EX KABALE & 27.8 \\
F $_{2}$ GULU-E X KATFM1 & 13.0 \\
GULU-E & 21.2 \\
IE2790 & 10.8 \\
KABALE & 25.2 \\
KATFM1 & 18.8 \\
Grand mean & 21.65 \\
\hline
\end{tabular}

$\mathrm{F}_{2}$ GULU-E X IE2790 and $\mathrm{F}_{2}$ GULU-E X KATFM1 fitted into 13R:3S segregation ratio indicating the presence of dominant epistasis (Table 6).Genotypes $F_{2}$ GULUXKABALE \& $F_{2}$ GULU-EXDR2 1 fitted in to (15R:1S), an evidence of duplicate gene interaction (Table 7).

\section{Discussion}

\begin{abstract}
Mode of inheritance
Mid-parent regression on $\mathrm{F}_{2}$ progenies was significant implying that the deviations from regression were significant. The regression equation does not properly explain the relationship between the mean of mid-parent and that of $\mathrm{F}_{2}$ population. There could be other unaccounted factors such physiological, structural and environmental influencing the phenotypic expression (disease response) not genetically backed. These need to be understood and incorporated in to breeding or integrated in to disease management.
\end{abstract}

Table 5. Mean disease severity of parents (p1and $p 2), F_{1}, F_{2}$ and mid parent values and measurement of heterosis as change from performance of mid-parent values from $F_{1}$ based on period after inoculation with Pyricularia grisea to infection of flag leaf

\begin{tabular}{|c|c|c|c|c|c|c|c|}
\hline Cross & $\mathrm{p} 1$ & $\mathrm{p} 2$ & $\mathrm{~F} 1$ & BCF1 & $\mathrm{F} 2$ & $\begin{array}{l}\text { Change of } \\
\text { MP from } \\
\text { F1 of } \% \\
\text { MP }\end{array}$ & Heterosis \\
\hline IE2790 x GULU-E & 10.8 & 21.2 & 11.2 & & 20 & -30 & Negative \\
\hline KATFM1 x GULU-E & 18.8 & 21.2 & 22.8 & & 13 & 14 & Positive \\
\hline KABALE x GULU-E & 25.2 & 21.2 & 31.8 & & 27.8 & 37 & positive \\
\hline DR21 x GULU-E & 13.4 & 21.2 & 18.9 & 18.4 & 15 & 9 & positive \\
\hline Mean & & & & & & 10.9 & \\
\hline
\end{tabular}

Estimation of components of generation means based on theoretical expectations (Singh and Chaudhary, 2007). $\quad \mathrm{F}_{1}=\mathrm{MP}=\mathrm{F}_{2}$ if genes are primarily additive. $\mathrm{F}_{2}=\left(\mathrm{F}_{\mathrm{I}}+\mathrm{MP}\right) / 2, \mathrm{BC}_{1}\left(\mathrm{P}^{1}\right)=\left(\mathrm{F}_{1}+\mathrm{P}^{1}\right) / 2 \quad \mathrm{BC}_{1}\left(\mathrm{P}^{2}\right)=$ $\left(\mathrm{F}_{1}+\mathrm{P}^{2}\right) / 2$ if both dominance $\&$ additive are present. $\mathrm{MP}=$ Mid parent, $\mathrm{BC}=\mathrm{Backross}, \mathrm{p} 1=$ parent $1 \mathrm{p} 2$ $=$ parent 2. Mid-parent heterosis $(\%)=\left(\mathrm{F}_{1}-\mathrm{MP}\right) / \mathrm{MP} \times 100$ 
Table 6. Analysis of gene interactions using Chi-square $\left(\mathrm{X}^{2}\right)$ test to determine departure of observed frequencies from theoretical expectations (13R:3S) classical dominant epistasis model

\begin{tabular}{lcrcc}
\hline Crosses & Phenotype & Observed & Expected & Chr-Sqr 0.05 \\
\hline F FULU x KATFM1 & $\mathrm{R}$ & 24 & 20.3 & 0.67 \\
& $\mathrm{~S}$ & 1 & 4.69 & 2.9 \\
& Total & 25 & 24.99 & $3.57^{*}$ \\
& & & & \\
F F $_{2}$ GULU x KABALE & $\mathrm{R}$ & 24 & 20.3 & 0.024 \\
& $\mathrm{~S}$ & 1 & 4.69 & 0.011 \\
& Total & 25 & 24.99 & $0.035 \mathrm{~ns}$ \\
F $_{2}$ GULU x IE2790 & & & & \\
& $\mathrm{R}$ & 13 & 20.3 & 2.63 \\
& $\mathrm{~S}$ & 11 & 24.99 & 8.49 \\
& Total & 24 & 24.99 & $11.09 *$ \\
F $_{2}$ GULU x DR21 & & & & \\
& $\mathrm{R}$ & 17 & 20.3 & 0.54 \\
& $\mathrm{~S}$ & 8 & 1.57 & 2.34 \\
& Total & 25 & 24.9 & $2.88 \mathrm{~ns}$ \\
\hline
\end{tabular}

Based on scale of 1-5 disease severity ratings for leaf blast modified from Takan $e$ t al., 2011. Scores 1-3 for severity were considered resistant $(\mathrm{R})$ that is $30 \%$ of leaf area covered by lesions and scores( 4-5) severity as susceptible(S) with more than $30 \%$ leaf area covered by lesions. Significant goodness of fit $* \mathrm{P}<0.05$. $30 \%$ leaf area covered by lesions (Takan et al., 2011). Significant goodness of fit $* \mathrm{P}<0.05, * * * \mathrm{P}<0.001$

Table 7. Analysis of gene interactions using Chi-square $\left(\mathrm{X}^{2}\right)$ test to determine departure of observed frequencies from theoretical expectations (15R:1S) classical duplicate gene interaction

\begin{tabular}{llccc}
\hline Cross & Phenotype & Observed & Expected & Chr - Sqr \\
\hline F GULU X KATFM1 & $\mathrm{R}$ & 24 & 23.4 & 0.02 \\
& $\mathrm{~S}$ & 1 & 1.57 & 0.21 \\
& Total & 25 & 24.97 & $0.23 \mathrm{~ns}$ \\
& & & & \\
F $_{2}$ GULU X KABALE & $\mathrm{R}$ & 21 & 23.4 & 0.25 \\
& $\mathrm{~S}$ & 4 & 1.57 & 3.76 \\
& Total & 25 & 24.97 & $4.01^{*}$ \\
F F GULU X IE2790 $_{2}$ & $\mathrm{R}$ & & & \\
& $\mathrm{S}$ & 13 & 23.4 & 4.62 \\
& Total & 24 & 1.57 & 56.64 \\
F $_{2}$ GULU X DR21 & $\mathrm{R}$ & 24.97 & $61.26^{* *}$ \\
& $\mathrm{~S}$ & 17 & 23.4 & 1.75 \\
& Total & 8 & 1.57 & 26.33 \\
& & 25 & 24.97 & $28.08^{* * *}$ \\
\hline
\end{tabular}

Disease severity rating scale of 1-5; Scores 1-3 severity were considered resistant (R) that is $30 \%$ of leaf area covered by lesions and scores $4-5$ severity as susceptible(S) with more than $30 \%$ leaf area covered by lesions (Takan et al., 2011). Significant goodness of fit *P<0.05, *** $\mathrm{P}<0.001$ 
Combined analysis of variance of generations showed significance, implying presence of genetic variability for selection at early generations. The genetic components of this variance were both non-additive and additive. The additive variance being controlled by many genes is influenced by environment, which is supported by moderate narrow sense heritability(Holland et al., 2003). Low narrow sense heritability could have also been due to the small sample size; therefore, it is necessary to verify these findings using a, large population. But nevertheless, presence of heterosis on either direction indicates presence of two types of gene action.

\section{Nature of genetic resistance}

Although blast resistance is controlled mainly by major genes (Oduori, 2008), from this study it's expression in some crosses could have depended on the system of polygenic modifiers, depending on the genetic background and environment. GULU-E X KABALE and GULU-E X DR21 have good specific combining ability that could be exploited in development of improved varieties based on expression of low infection. The expression of chlorotic-lesion resistance is enhanced in a background containing genes for lesion-number resistance and flag leaf resistance. There is evidence from several variance estimation studies that epistasis is common in self pollinated crops such as finger millet. Dominance variance might also contain epistatic variances if epistasis is present. This is in agreement with the findings from Pswarayi A and Vivek. B., (2008) that genes with major or minor effect will function differently in different genetic background.

\section{Breeding strategy}

A combination of major resistance with quantitative resistance becomes a promising breeding strategy for reducing the rate of disease epidemic. Both forms of resistance are present in GULU-E and are responsible for preserving its durability overtime. The fact that resistance breakdown frequency due to major gene is high, this cultivar could have been naturally eliminated because one gene could not contain the necessary variability for resistance to such a variable pathogen given that finger millet is highly self pollinating crop. Therefore, from the study, it is possible to accumulate genes for race specific resistance in host cultivars through modified at backcrossing that might reduce development of disease epidemics in some areas. Major genes together can exhibit additive gene effect and when dominant genes become more frequent they tend increase on the days to infection of the flag leaf and overall rate of growth of the pathogen slowed. The frequency of dominant genes against virulent pathogen populations in our environment can be accumulated through modified backcrossing at $\mathrm{F}_{3}$. The findings are in line with the hypothesized breeding strategy for breeding for durability in pepper cultivars (Capsicum annum) attacked by potato virus Y (Poty virus) (Ruth et al., 2001). There could also be physiological/bio-chemical mechanisms responsible for increasing days to infection of the flag leaf which needs to be understood and incorporated in to breeding for resistance.

\section{Acknowledgement}

Financial support by Bio-innovate and Mcknight through RUFORUM is highly 
appreciated. I am also grateful to Makerere University for the Msc. training, the National Semi Arid Resources Research Institute (NaSARRI) for availing the finger millet germplasm, supervision and facilitation to participate in this conference.

\section{References}

Adipala, E. and Wandera. 2001. Variation in pathogenicity of Uganda finger millet pyricularia grisea isolates. Africa Crop Science Conference Proceedings 5:369-379.

Aru, J. 2014. On genetic improvement of drought tolerant finger millet for blast resistance in Uganda. Msc. Thesis. Makerere University, Kampala, Uganda. 69pp.

Getachew Gashaw, Tesfaye Alemu and Kassahum Tesfaye. 2013. Chararcterization of finger millet Blast Pathogen and its management using Bio-controls and fungicides. First Bioinnovate regional conference February, 25-27 2013. UNCC-ECA Addis Ababa, Ethiopia.

Holland, J.B.W.E. and CervantezMartinez, C.T. 2003 Estimating and interpreting heritability for plant breeding:An update. Plant Breeding Rewiews 22:9-112.

Mukankusi, C., Adipala, E., Kyamanya, S., Epieru, G., Odeke, V., Warren, H.L. and Wilson, H.R 1999. Effect of host type, time of planting,spacing of groundnut rosette and cercospora leaf spot diseases in eastern Uganda. African Journal of Plant Protection.

Oduori, C. 2008. Breeding investigations of finger millet characteristics including blast disease and striga resistance in western Kenya (PhD) Thesis in Plant Breeding. University of KwaZulu-Natal Republic of South Africa. 202pp.

Pswarayi, A. and Vivek, B. 2008. Combining ability amongst CIMMYT's early maturing maize (Zea mays L.) germplasm under stress and on stress conditions and identification of testers. Euphytica 162:353-362

Ruth, M., Solomon., B. and Hugh, B. 2001. A review of host major gene resistance to potato viruses. Heredity 86:8-16.

Singh, R.K.and Chaudhary, B.D. 2007. Biometrical methods in quantitative genetic analysis. Kalyani publishers, New Delhi, India. 774pp.

Takan, J.P., Muthumeenakshi, S., Sreenivasaprasad, S., Akello, B., Obilana, A., Bandyopadhyay, R., Coll, R., Brown, A.E. and Talbot, N.J. 2002. Characterisation of finger millet blast pathogen populations in East africa and strategies for disease management. In: Plant Pathology: Global Food Security, BSPP conference, Imperial College, London, 8-10.

Takan, J.P., Akello, B., Esele, P., Manyasa, E.O., Obilana, A.B. and Audi, P.O 2004. Finger millet blast pathogen diversity and management in East Africa: A summary of project activities and outputs. International Sorghum and Millets Newsletter 45:66-69.

Takan, J.P. 2007. A study on the genetic diversity, sexuality and pathogenicity of the finger millet blast pathogen Magnaporthe grisea populations in two East African countries. PhD Thesis, University of Exeter, UK. 315pp. 